\title{
ANALISIS DAMPAK SHOCK VOLUME PERDAGANGAN SAHAM PADA INDEKS HARGA SAHAM CONSUMER GOODS DENGAN STRUCTURAL VECTOR AUTOREGRESSIVE (SVAR)
}

\author{
Infan Nur Kharismawan ${ }^{1}$, Rukun Santoso ${ }^{2}$, Budi Warsito ${ }^{3}$ \\ 1,2,3 Departemen Statistika, Fakultas Sains dan Matematika, Universitas Diponegoro \\ e-mail : rukunsantoso25@gmail.com
}

\begin{abstract}
The stock trading in the capital market will result daily volume of trading stock that impact on stock price. One of the indicators that describes the stock price movement is stock index. There are many types of stock index, one of them is consumer goods stock index. Stock index is a sensitive economic variable affected by shock and need a restriction to form its economic model. Based on that, Structural Vector Autoregressive (SVAR) is used to describe its economic model. SVAR is formed by a stable VAR, fulfilled white noise, kvariate normal distribution. The purpose of this study are to forecast data on each variables and analyze the impact of the shock through the descriptions of variance decomposition. VAR used as the basis for SVAR is VAR(8) whose the forming variable stationary at the first different degree. Performances of forecasting SVAR using MAPE (Mean Absolute Percentage Error) for in sample data are $13.87434 \%$ (volume of trading stock) and $0.87045 \%$ (consumer goods stock index) and for out sample data are $14.22964 \%$ (volume of trading stock) and $1.76054 \%$ (consumer goods stock index). Response of consumer goods stock index to the impact of the volume of trading stock shock shown by proportion of variance decomposition tends to increase, while the shock by itself has decreased until reach its equilibrium point.
\end{abstract}

Keywords:cosumer goods stock index, SVAR, variance decomposition, volume of trading stock

\section{PENDAHULUAN}

Investasi umumnya dibedakan menjadi 2 berdasarkan bentuknya yaitu investasi aktiva finansial dan investasi aktiva riil. Investasi aktiva finansial merupakan bentuk investasi yang penanaman modalnya ditujukan pada instrumen keuangan di pasar modal. Investasi bentuk ini merupakan kepemilikan hak klaim atau aktiva yang diwujudkan dalam bentuk dokumen legal yang disebut sekuritas (surat berharga) (Sunariyah, 2010).

Investasi saham tidak terlepas dari suatu indeks yang mencerminkan pergerakan harga saham yang dinamakan indeks saham. Indekssaham merupakan salah satu pedoman untuk melakukan investasi saham di pasar modal, karena naik turunnya indeksberdampak pada harga saham dari emitennya. Salah satu indeks saham adalah indeks saham consumer goods yang terdiri dari gabungan perusahaan manufaktur sektor industri barang konsumsi.

Fluktuasi harga saham mengikuti perkembangan volume perdagangan saham setiap harinya. Volume perdagangan saham adalah keseluruhan transaksi pembelian maupun penjualan saham yang dilakukan investor. Meningkatnya volume perdagangan saham karena didominasi oleh aksi beli mengakibatkan peningkatan harga saham. Peningkatan harga saham akan menyebabkan indeks saham bergerak naik (Darmadji dan Fakhtudidin, 2001).

Model VAR digunakan untuk membentuk model Structural Vector Autoregressive (SVAR). SVAR merupakan bentuk VAR yang terestriksi dengan restriksinya berdasarkan hubungan teoritis yang kuat antar variabel dalam sistem VAR. Restriksi yang digunakan dalam penelitian ini mengacu pada teori saham bahwa harga saham yang digambarkan dengan indeks saham consumer goods dipengaruhi oleh volume perdagangan saham. Model SVAR dalam penelitian ini digunakan untuk meramalkan indeks saham consumer goods dan volume perdagangan saham serta untuk menganalisis dampak shock volume perdagangan saham pada indeks saham consumer goods melalui uraian variance decomposition 


\section{TINJAUANPUSTAKA}

\subsection{Pasar Modal}

Pasar modal diartikan sebagai tempat bertemunya antara penjual dan pembeli yang memperdagangkan surat-surat berharga jangka panjang. Tujuan utama pasar modal adalah memfasilitasi perdagangan atas klaim terhadap bisnis perusahaan. (Sunariyah, 2010). Instrumen investasi di pasar modal yang disebut efek ialah semua surat berharga yang diperjualbelikan melalui pasar modal yang tediri atas berbagai macam jenisnya.

Perusahaan publik yang tercatat di BEI diklasifikasikan menjadi 9 sektor yang digolongkan menjadi 3 bagian yaitu sektor utama, manufaktur, dan jasa. Salah satu sektor BEI adalah industri barang konsumsi yang merupakan bagian dari golongan manufaktur. Sektor industri barang konsumsi memiliki keterkaitan tinggi dengan konsumen karena aktivitas dari perusahaannya bertugas memproduksi barang kebutuhan masyarakat. Sektor industri barang konsumsi terdiri atas 5 subsektor yaitu subsektor makanan dan minuman, rokok, farmasi, kosmetik dan barang keperluan rumah tangga, serta peralatan rumah tangga.

Volume perdagangan saham ialah salah satu indikator likuiditas saham atas suatu informasi yang ada dalam pasar modal. Menurut Halim dan Hidayat (2000), volume perdagangan saham merupakan jumlah lembar saham yang diperdagangkan pada hari tertentu. Perdagangan saham yang aktif ditunjukkan dengan besarnya volume perdagangan menyebabkan harga saham bergerak naik (Rusdin, 2008). Peningkatan volume perdagangan saham yang diiringi kenaikan harga saham merupakan gejala kondisi pasar yang menguat.

\subsection{Model Autoregressive (AR)}

Soejoeti (1987) menyatakan bahwa autoregressive adalah model terhadap dirinya sendiri. Persamaan model autoregressive dengan orde $\mathrm{p}$ adalah sebagai berikut:

$$
Z_{t}=\emptyset_{1} Z_{t-1}+\emptyset_{2} Z_{t-2}+\ldots+\emptyset_{\mathrm{p}} Z_{t-\mathrm{p}}+\varepsilon_{t}
$$

dengan:

$Z_{t}, Z_{t-\mathrm{p}}:$ nilai observasi pada saat $t=1$ hingga $t-i, i=1,2, \ldots, \mathrm{p}$

$\emptyset_{i} \quad:$ koefisien/parameter dari model autoregressive saat $\mathrm{i}=1,2, \ldots, \mathrm{p}$

$\varepsilon_{t} \quad$ : nilai residual pada waktu ke- $t$

\subsection{Uji Stasioneritas}

Stasioneritas diartikan tidak terdapat perubahan yang drastis pada data (Makridakis et al, 1992). Rosadi (2012) menambahkan bahwa stasioneritas berarti fluktuasi data runtun waktu berada di sekitar nilai rata-rata serta varian yang konstan sepanjang waktunya.

Aunuddin (1989) menyatakan bahwa metode Box-Cox adalah salah satu metode untuk menstasionerkan data yang tidak stasioner dalam varian dengan transformasi pangkat $(\lambda)$ pada respon yang dirumuskan sebagai berikut:

$$
T\left(Z_{t}\right)= \begin{cases}\frac{z_{t}^{\lambda}-1}{\lambda}, & \lambda \neq 0 \\ \ln Z_{t}, & \lambda=0\end{cases}
$$

Hill et al (2011) menyatakan bahwa data dikatakan stasioner dalam mean apabila tidak adatrend,dan sebaran datanya di sekitar rata-rata yang konstan. Uji stasioneritas dalam mean dilakukan denganAugmented Dickey Fuller Test(ADF-test). Diferensi dilakukan untuk mengatasi ketidakstasioneran dalam mean (Makridakis et al, 1992).

Gujarati (2004) menyatakan bahwa langkah melakukan ADF-test adalah sebagai berikut:

1. Menentukan hipotesis pengujian 
$H_{0}:|\varnothing|=1$ (terdapat akar unit atau data tidak stasioner)

$H_{1}:|\varnothing|<1$ (tidak terdapat akar unit atau data stasioner)

2. Menentukan taraf signifikansi $(\alpha)$

3. Menghitung statistik uji

$$
\text { t-hitung }=\left|\frac{\widehat{\phi}-1}{S E(\widehat{\varnothing})}\right|
$$

4. Kriteria ujinya adalah menolak $H_{0}$ apabila t-hitung $>\mid \mathrm{ADF}$ tabel $\mid$ atau $p$-value $<\alpha$

\subsection{Model Vector Autoregressive}

Vector autoregressive (VAR) merupakan analisis yang persamaan simultannya mempertimbangkan beberapa variabel terikatsecara bersama.Lütkepohl (2005) menyatakan bahwa persamaan VAR dengan jumlah variabel $\mathrm{k}$ dan lag $\mathrm{p}$ adalah sebagai berikut:

$$
Z_{t}=\Phi_{0}+\Phi_{1} Z_{t-1}+\ldots+\Phi_{\mathrm{p}} Z_{t-\mathrm{p}}+\varepsilon_{t}
$$

dengan:

$\boldsymbol{Z}_{\boldsymbol{t}}, \boldsymbol{Z}_{\boldsymbol{t}-\mathrm{p}}$ : vektor berisi k variabel dalam model VAR saat $t=1$ hingga $t-i, i=1,2, \ldots, \mathrm{p}$

$\boldsymbol{\Phi}_{\mathbf{0}} \quad$ : vektor ukuran k x 1 berisi konstanta

$\boldsymbol{\Phi}_{\boldsymbol{i}} \quad$ : matriks parameter variabel berukuran $\mathrm{k} x \mathrm{k}$ untuk setiap i $=1,2, \ldots, \mathrm{p}$

$\boldsymbol{\varepsilon}_{\boldsymbol{t}} \quad$ : vektor residual pada waktu ke- $t$

Pendugaan parameter model VAR digunakan metode OLS agar mendapatkan model yang memiliki residual minimum (Ariefianto, 2012). Gujarati (2004) menyatakan untuk memperoleh estimasi OLS ditulis dalam bentuk linier sebagai berikut:

$$
\mathbf{Y}=\mathbf{Z} \beta+\varepsilon
$$

dengan:

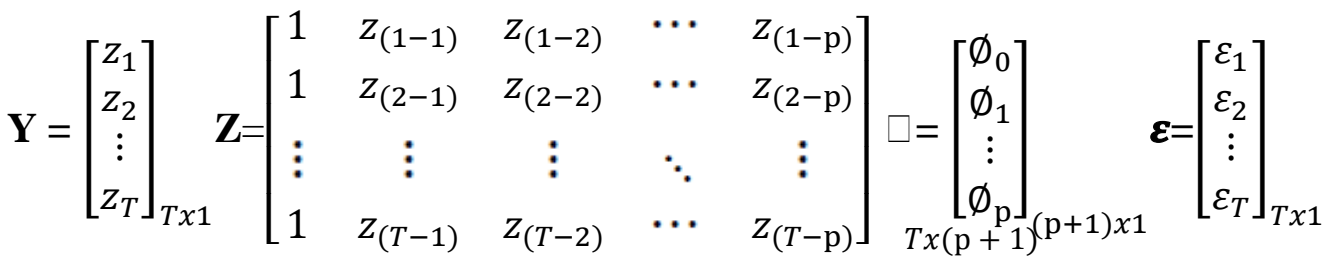

Parameter $\beta$ ditaksir dengan mengkuadratkan residualnya sebagai berikut:

$$
\boldsymbol{\varepsilon}^{\prime} \varepsilon=(\mathbf{Y}-\mathbf{Z} \boldsymbol{\beta})^{\prime}(\mathbf{Y}-\mathbf{Z} \boldsymbol{\beta})
$$

$$
\mathbf{Y}^{\prime} \mathbf{Y}-2 \beta^{\prime} \mathbf{Z}^{\prime} \mathbf{Y}+\boldsymbol{\beta}^{\prime} \mathbf{Z}^{\prime} \mathbf{Z} \boldsymbol{\beta}
$$

Syarat perlu adalah turunan pertama $\boldsymbol{\varepsilon}^{\prime} \boldsymbol{\varepsilon}$ terhadap $\boldsymbol{\beta}$ disama dengankan nol yaitu:

$$
\frac{\partial \varepsilon^{\prime} \boldsymbol{\varepsilon}}{\partial \boldsymbol{\beta}}=-2 \mathbf{Z}^{\prime} \mathbf{Y}+2 \mathbf{Z}^{\prime} \mathbf{Z} \boldsymbol{\beta}=0
$$

Kemudian dilakukan turunan kedua dari $\boldsymbol{\varepsilon}^{\prime} \boldsymbol{\varepsilon}$ terhadap $\boldsymbol{\beta}$ sebagai syarat cukup sebagai berikut:

$$
\frac{\partial^{2} \varepsilon^{\prime} \varepsilon}{\partial \beta^{2}}=2 Z^{\prime} \mathbf{Z}
$$

Matriks $\mathbf{Z}^{\prime} \mathbf{Z}$ ialah matriks definit positif karena $\left|\mathbf{Z}^{\prime} \mathbf{Z}\right|>0$. Syarat perlu dan syarat cukup untuk meminimumkan residual sudah terpenuhi maka formula OLS adalah sebagai berikut: 


$$
\widehat{\beta}=\left(\mathbf{Z}^{\prime} \mathbf{Z}\right)^{-1} \mathbf{Z}^{\prime} \mathbf{Y}
$$

Rosadi (2012) menyatakan bahwa lag p yang optimum dapat digunakan kriteria informasi AIC (akaike information criterion). Lag optimum adalah lag dengan nilai AIC terkecil. Persamaan AIC diformulasikan sebagai berikut

$$
\operatorname{AIC}(\mathrm{p})=\ln \left(\operatorname{det}\left(\sum_{\mathbf{p}}\right)\right)+\frac{2 k^{2} \mathbf{p}}{T}
$$

dengank adalah banyaknya variabel pada model, $\Sigma_{\mathbf{p}}$ adalah matriks varian-kovarian residual, padalah banyaknya lag, dan Tadalah banyaknya observasi.

\subsection{Uji Kausalitas Granger}

Uji kausalitas granger digunakan untuk melihat hubungan sebab akibat antar variabel dalam VAR. Menurut Gujarati (2004) tahap uji kausalitas granger sebagai berikut:

1. Menentukan hipotesis pengujian

$H_{0}: \emptyset_{j i}=0 \square(\mathrm{j}, \mathrm{i}), \mathrm{j}=1,2,3, \ldots, \mathrm{k}$ dan $\mathrm{i}=1,2,3, \ldots, \mathrm{p}$ (variabel satu tidak berpengaruh terhadap variabel lain)

$H_{1}$ : paling sedikit ada satu i sehingga $\emptyset_{j i} \neq 0$ (variabel satu berpengaruh terhadap variabel lain)

2. Menentukan taraf signifikansi $(\alpha)$

3. Menghitung statistik uji

$\mathrm{F}=\frac{\left(R S S_{R}-R S S_{U R}\right) / p}{R S S_{U R} /(T-m)}$

dengan $R S S_{R}$ adalah residual sum square restricted, $R S S_{U R}$ adalah residual sum square unrestricted dan $\mathrm{m}$ adalah banyaknya parameter yang diestimasi.

4. Kriteria ujinya adalah menolak $H_{0}$ apabila $\mathrm{F}>\mathrm{F}_{(\alpha ; p,(\mathrm{~T}-\mathrm{m}))}$ atau $p$-value $<\alpha$

\subsection{Uji Asumsi Residual}

Salah satu uji asumsi residual ialah uji white noise yaitu jika residual tidak berkorelasi dengan rata-rata nol, varian konstan yaitu $\sigma^{2}$ dan $\operatorname{Cov}\left(\varepsilon_{t}, \varepsilon_{t+k}\right)=0$ untuk $\mathrm{k} \neq$ 0 . Menurut Lütkepohl (2005) ujiwhite noise dengan statistikportmanteau sebagai berikut:

1. Menentukan hipotesis pengujian

$H_{0}$ : residual telah memenuhi proses white noise

$H_{1}$ : residual tidak memenuhi proses white noise

2. Menentukan taraf signifikansi $(\alpha)$

3. Menghitung statistik uji

$$
Q_{h}=T \sum_{j=1}^{h} \operatorname{tr}\left(\hat{C}_{j}^{\prime} \hat{C}_{0}^{-1} \hat{C}_{j} \hat{C}_{0}^{-1}\right)
$$

4. Kriteria ujinya adalah menolak $H_{0}$ apabila $Q_{h} \geq \chi_{\alpha ;\left(k^{2}\left(\mathrm{~h}-n^{*}\right)\right)}^{2}$ dengan $n^{*}$ adalah jumlah koefisien selain konstanta, $\mathrm{h}$ adalah lag residual, $\mathrm{k}$ adalah banyaknya variabel.

Selain uji white noise, uji asumsi residual lainnya adalah normalitas $\mathrm{k}$ variat.Menurut Haryatmi dan Guritno (2008), jika $\boldsymbol{X}_{\boldsymbol{i}}\left(\boldsymbol{\varepsilon}_{\boldsymbol{t}}\right)$ adalah sampel random normal kvariat dengan vektor mean $\boldsymbol{\mu}$ dan matriks varian-kovarian $\sum$, maka jarak mahalanobisnya adalah:

$$
d_{i}^{2}=\left(\boldsymbol{X}_{\boldsymbol{i}}-\boldsymbol{\mu}\right)^{\prime} \Sigma^{-1}\left(\boldsymbol{X}_{\boldsymbol{i}}-\boldsymbol{\mu}\right), i=1,2, \ldots, T
$$


akan berdistribusi $\chi_{k}^{2}$. Sehingga uji normalitas k-variat dirumuskan sebagai berikut:

1. Menentukan hipotesis pengujian

$H_{0}: F\left(d_{i}^{2}\right)=F^{*}\left(d_{i}^{2}\right)\left(d_{i}^{2}\right.$ berdistribusi $\left.\chi_{k}^{2}\right)$

$H_{1}: F\left(d_{i}^{2}\right) \neq F^{*}\left(d_{i}^{2}\right)\left(d_{i}^{2}\right.$ tidak berdistribusi $\left.\chi_{k}^{2}\right)$

2. Menentukan taraf signifikansi $(\alpha)$

3. Menghitung statistik uji

$\mathrm{D}=\operatorname{Sup}\left|F^{*}\left(d_{i}^{2}\right)-F\left(d_{i}^{2}\right)\right|$

$F^{*}\left(d_{i}^{2}\right)$ menyatakan fungsi distribusi kumulatif yang dihipotesiskan dan $F\left(d_{i}^{2}\right)$ adalah fungsi distribusi dari sampel yang teramati (fungsi distribusi kumulatif empirik).

4. Kriteria ujinya adalah menolak $H_{0}$ jika $\mathrm{D} \geq D_{(1-\alpha)}$ ataup-value $<\alpha$.

\subsection{Uji Stabilitas VAR}

Rosadi (2012) menjelaskan bahwa model VAR(p) yang stabil ialah jika semua root terletak dalam unit circle. Implikasi dari model yang tidak stabil diperkirakan akan menghasilkan variance decomposition yang sulit menuju kondisi keseimbangannya (equilibrium) untuk periode jangka panjangnya.

\subsection{Structural Vector Autoregressive(SVAR)}

Metode SVAR digunakan untuk membuat restriksi (A) sehingga model VAR akan sejalan dengan teori yang ada. Restriksi mengacu pada spesifikasi $\mathbf{A} \boldsymbol{\varepsilon}_{\boldsymbol{t}}=\boldsymbol{\mu}_{\boldsymbol{t}}$. Lütkepohl (2005) menyatakan bahwa SVAR dengan lag p memiliki bentuk umum sebagai berikut:

dengan:

$$
\mathrm{A} Z_{t}=\Gamma_{0}+\Gamma_{1} Z_{t-1}+\ldots+\Gamma_{\mathrm{p}} Z_{t-\mathrm{p}}+\mu_{t}
$$

$$
\mathbf{A}:\left[\begin{array}{cc}
1 & a_{12} \\
a_{21} & 1
\end{array}\right]
$$

\subsection{Kinerja Model}

Model terbaik didasarkan pada nilai residual ramalan in sample dan out sample. Model dikatakan baik jika memiliki nilai MAPE (mean absolute percentage error) yang kecil (Chang et al, 2007). Persamaan untuk menghitung MAPE adalah sebagai berikut:

$$
\operatorname{MAPE}=\frac{1}{T} \sum_{t=1}^{T}\left|\frac{Z_{t}-\hat{Z}_{t}}{Z_{t}}\right| \times 100 \%
$$

dengan:

$Z_{t} \quad$ : nilai aktual saat periode ke- $t$

$\hat{Z}_{t} \quad$ : nilai prediksi saat periode ke- $t$

$\mathrm{T} \quad$ : banyaknya observasi

\subsection{Variance Decomposition}

Variance decomposition memberikan informasi pergerakan pengaruh shockpada sebuah variabel terhadap shock variabel lain (Enders, 2004). Lütkepohl (2005) menyatakan bahwa proporsi variance decomposition hingga periode ke-h dirumuskan sebagai berikut:

$$
\omega_{x y, h}=\sum_{i=h}^{h-1}\left(\boldsymbol{e}_{\boldsymbol{x}}^{\prime} \boldsymbol{\Theta}_{\boldsymbol{i}} \boldsymbol{e}_{\boldsymbol{y}}\right)^{2} / \sum_{i=0}^{h-1} \sum_{k=1}^{K} \theta_{j k, i}^{2}
$$


dengan:

$\boldsymbol{e}_{\boldsymbol{y}} \quad$ : kolom dari matriks $\mathbf{I}_{\mathbf{y}}$

$\boldsymbol{e}_{\boldsymbol{x}} \quad$ : kolom dari matriks $\mathbf{I}_{\mathbf{x}}$

$\boldsymbol{\Theta}_{\boldsymbol{i}}$ : matriksimpulse dengan $\boldsymbol{\Theta}_{\boldsymbol{i}}=\boldsymbol{\varphi}_{\boldsymbol{i}} \mathrm{A}$ dan $\boldsymbol{\varphi}_{\boldsymbol{i}}=\sum_{j=\mathbf{1}}^{\boldsymbol{i}} \boldsymbol{\varphi}_{\boldsymbol{i}-\boldsymbol{j}} \boldsymbol{\Phi}_{\boldsymbol{j}}$ dengan $\boldsymbol{\varphi}_{\mathbf{0}}=\mathbf{I}$

$\theta_{j k, i}:$ elemen dari matriks $\boldsymbol{\Theta}_{\boldsymbol{i}}$

\section{METODOLOGI PENELITIAN}

\subsection{Jenis dan Sumber Data}

Data yang digunakan adalah data sekunder yang merupakan data harian dari 4 Agustus 2017 hingga 26 Juni 2018 yang dipublikasikan melaluihttps:/investing.com/. Variabel penelitian yang digunakan adalah $Z_{1 t}$ untuk volume perdagangan saham dan $Z_{2 t}$ untuk indeks saham consumer goods. Volume perdagangan saham menggunakan satuan juta lembar saham dan indeks saham consumer goods menggunakan harga penutupannya.

\subsection{Langkah-Langkah Penelitian}

Langkah-langkah penelitian ini adalah sebagai berikut:

1. Melakukan uji stasioneritas dalam varian dengan metode Box-Cox dan uji stasioneritas dalam mean denganaugmented dickey fuller Test (ADF-test).

2. Menentukan lag optimum dengan memilih nilai AIC yang terkecil dari lag maksimum yang digunakan dan membuat model VAR dengan lag optimumnya.

3. Melakukan uji kausalitas granger untuk mengetahui hubungan timbal balik variabel.

4. Melakukan uji asumsi residual yaitu uji white noise dan uji normalitas k-variat.

5. Melakukan uji stabilitas VAR dengan inverse roots of AR characteristic polynomial.

6. Melakukan penaksiran matriks Adan membentuk model SVAR untuk melakukan peramalan serta menghitung kinerja model menggunakan MAPE.

7. Menentukan variance decompositionuntuk analisis dampak shock.

\section{HASIL DAN PEMBAHASAN}

Metode Box-Cox digunakan untuk menguji stasioneritas dalam variandengan volume perdagangan saham memiliki $\lambda=-0,50$ dan indeks saham consumer goods memiliki $\lambda=2,00$. Karena $\lambda$ tidak bernilai 1,00 sehingga harus dilakukan transformasi pangkat dan diperoleh $\lambda$ yang bernilai 1,00 pada setiap variabel maka disimpulkan bahwa keduanya sudah stasioner dalam varian. Uji stasioneritas dalam mean dilakukan menggunakan ADF-test. Hasil pengujian pada derajat level menunjukkan bahwa kedua variabel tidak stasioner dalam mean karena $p$-value $>\alpha(5 \%)$ yaitu 0,1235 untuk volume perdagangan saham dan 0,6038 untuk indeks saham consumer goods sehingga harus dilakukan diferensi orde pertama dan disimpulkan bahwa kedua variabel telah stasioner dalam mean karena $p$-value $<\alpha(5 \%)$ yaitu 0,000 untuk variabel volume perdagangan saham dan indeks saham consumer goods.

Model VAR dibentuk dengan data yang telah ditransformasi dan dilakukan diferensi berdasarkan lag optimum yang memiliki nilai AIC terkecil yaitu pada lag ke-8 dengan AIC bernilai18,74576 sehingga model VAR yang terbentuk adalah VAR(8) sebagai berikut:

a. Persamaan D(TVolume Perdagangan Saham)

$$
\begin{aligned}
& \mathrm{DT} Z_{1 t}=-0,00018908-0,71881701 \mathrm{D} Z_{1 t-1}-0,7098170 \mathrm{D} Z_{1 t-2}-0,54008186 \\
& \mathrm{D}_{1 t-3^{-}} \quad 0,54440893 \quad \mathrm{DZ}_{1 t-4^{-}} \quad 0,43990211 \quad \mathrm{D} Z_{1 t-5}-0,25514564 \quad \mathrm{D} Z_{1 t-6^{-}}
\end{aligned}
$$


$0,23737440 \mathrm{D} Z_{1 t-7}-0,19134005 \mathrm{D} Z_{1 t-8}+9,20352 \mathrm{E}-10 \mathrm{D} Z_{2 t-1}+3,92042 \mathrm{E}-$

$10 \mathrm{D} Z_{2 t-2}+1,68632 \mathrm{E}-10 \mathrm{D} Z_{2 t-3}+2,67049 \mathrm{E}-09 \mathrm{D} Z_{2 t-4}+2,52062 \mathrm{E}-09$ $\mathrm{D} Z_{2 t-5}-1,74351 \mathrm{E}-09 \mathrm{D} Z_{2 t-6}+1,40941 \mathrm{E}-09 \mathrm{D} Z_{2 t-7}+3,90407 \mathrm{E}-09 \mathrm{D} Z_{2 t-8}$

b. Persamaan D(TIndeks Saham Consumer Goods)

$$
\begin{aligned}
& \mathrm{DT}_{2 t}=-3270,7348-4302568,56 \mathrm{D} Z_{1 t-1}-9419786,67 \mathrm{D} Z_{1 t-2}-11518317,8 \mathrm{D} Z_{1 t-3}- \\
& 9782437,85 \mathrm{D} Z_{1 t-4}-8121980,61 \mathrm{D} Z_{1 t-5}-6279515,56 \quad \mathrm{D} Z_{1 t-6}+ \\
& 3156572,05 \mathrm{D} Z_{1 t-7}+3983094,72 \mathrm{D} Z_{1 t-8}-0,07228907 \mathrm{D} Z_{2 t-1}+ \\
& 0,00187977 \mathrm{D} Z_{2 t-2}-0,02522519 \mathrm{D} Z_{2 t-3}+0,09374503 \mathrm{D} Z_{2 t-4}- \\
& 0,05573842 \mathrm{D} Z_{2 t-5}-0,00495236 \mathrm{D} Z_{2 t-6}+0,09932156 \mathrm{D} Z_{2 t-7} \quad- \\
& 0,07909822 \mathrm{D} Z_{2 t-8}
\end{aligned}
$$

Uji kausalitas granger dilakukan untuk melihat hubungan antar variabel dalam sistem VAR. Hubungan yang terjadi bisa dalam satu arah atau dua arah. Hubungan satu arah terjadi jika variabel volume perdagangan saham mempengaruhi indeks saham consumer goods atau sebaliknya. Sedangkan hubungan dua arah terjadi jika antar variabel saling mempengaruhi. Pada taraf signifikansi5\% disimpulkan bahwa hubungan yang terjadi adalah satu arah yaitu volume perdagangan saham mempengaruhi indeks saham consumer goods.

Salah satu asumsi residual yang perlu diuji dalam model VAR adalah uji white noise untuk melihat korelasi residual antar lag dalam model VAR. Pengujian white noise residual menggunakan statistik uji portmanteau yang hasilnya terdapat pada Tabel 1.

Tabel 1. Uji White Noise Residual

\begin{tabular}{cccl}
\hline Lags & Q-Stat & P-Value & Df \\
\hline 1 & 0,143458 & NA* $^{*}$ & NA* \\
2 & 0,627335 & NA* $^{*}$ & NA* \\
3 & 1,413361 & NA* $^{*}$ & NA* \\
4 & 1,866164 & NA* $^{*}$ & NA* \\
5 & 2,85832 & NA* $^{*}$ & NA* \\
6 & 4,222987 & NA* $^{*}$ & NA* \\
7 & 5,348462 & NA* $^{*}$ & NA* \\
8 & 6,019976 & NA* $^{*}$ & NA* \\
9 & 8,684355 & 0,0695 & 4 \\
10 & 10,66602 & 0,2214 & 8 \\
11 & 14,74214 & 0,2558 & 12 \\
12 & 16,91334 & 0,3912 & 16 \\
13 & 22,03035 & 0,3389 & 20 \\
14 & 28,07346 & 0,2570 & 24 \\
15 & 28,94557 & 0,4153 & 28 \\
\hline
\end{tabular}

Pada taraf signifikansi $(\alpha) 5 \%$ disimpulkan bahwa asumsi white noise residual terpenuhi karena seluruh $p$-value dari uji portmanteau pada Tabel 1 lebih besar dari 5\%.

Selain uji white noise, dalam VAR juga dilakukan uji normalitas k-variat menggunakan statistik kolmogorov-smirnov dan disimpulkan bahwa model $\operatorname{VAR}(8)$ berdistribusi normal k-variat karenap-value $(0,4051)$ lebih besar dari taraf signifikansi5\%.

Uji stabilitas VAR dilakukan dengan melihat unit circle inverse roots of autoregressive characteristic polynomial pada Gambar 1. Berdasarkan Gambar 1 disimpulkan bahwa VAR(8) dinyatakan stabil karena semua rootterletak pada unit circle. 


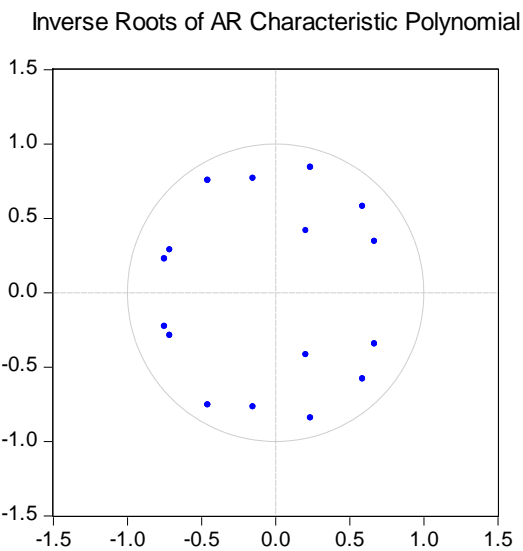

Gambar 1. Inverse Roots of Autoregressive Characteristic Polynomial

SVAR dibentuk dengan restriksi matriks $\mathbf{A}=\left[\begin{array}{cc}1 & 0 \\ -2716489 & 1\end{array}\right]$ mengacu bahwa indeks saham consumer goods dipengaruhi volume perdagangan saham. Persamaan model SVAR yang terbentuk adalah sebagai berikut:

a. Persamaan D(TVolume Perdagangan Saham)

$$
\begin{aligned}
\mathrm{DT} Z_{1 t}= & -0,00018908-0,71881701 \quad \mathrm{D} Z_{1 t-1}-0,7098170 \mathrm{D}_{1 t-2}-0,54008186 \\
& \mathrm{D} Z_{1 t-3^{-}} 0,54440893 \quad \mathrm{D} Z_{1 t-4}-0,43990211 \quad \mathrm{D} Z_{1 t-5}-0,25514564 \quad \mathrm{D} Z_{1 t-6^{-}} \\
& 0,23737440 \mathrm{D} Z_{1 t-7}-0,19134005 \quad \mathrm{D} Z_{1 t-8}+9,20352 \mathrm{E}-10 \mathrm{D} Z_{2 t-1}+3,92042 \mathrm{E}- \\
& 10 \mathrm{D} Z_{2 t-2}+1,68632 \mathrm{E}-10 \quad \mathrm{D} Z_{2 t-3}+2,67049 \mathrm{E}-09 \quad \mathrm{D} Z_{2 t-4}+2,52062 \mathrm{E}-09 \\
& \mathrm{D} Z_{2 t-5}-1,74351 \mathrm{E}-09 \mathrm{DZ}_{2 t-6}+1,40941 \mathrm{E}-09 \mathrm{D}_{2 t-7}+3,90407 \mathrm{E}-09 \mathrm{D} Z_{2 t-8}
\end{aligned}
$$

b. Persamaan D(TIndeks Saham Consumer Goods)

$$
\begin{array}{rlrr}
\mathrm{DT}_{2 t}= & -2757,0908-2349910,04 & \mathrm{D} Z_{1 t-1}-7491576,72 \mathrm{D} Z_{1 t-2}-10051191,4 \mathrm{D} Z_{1 t-3}- \\
& 8303556,98 \mathrm{D} Z_{1 t-4}-6926991,37 \mathrm{D} Z_{1 t-5}-5586415,251 & \mathrm{DZ}_{1 t-6} \\
& +3801397,004 \mathrm{D} Z_{1 t-7}+4502867,86 \mathrm{D} Z_{1 t-8}- & 0,06978894 \mathrm{D} Z_{2 t-1} \\
& +0,00081479 \mathrm{D} Z_{2 t-2}-0,02568327 \mathrm{D} Z_{2 t-3}+0,08649069 \mathrm{D} Z_{2 t-4}- \\
& 0,06258557 \mathrm{D} Z_{2 t-5}-0,00021613 \mathrm{D} Z_{2 t-6}+ & 0,09549291 \mathrm{D} Z_{2 t-7} & - \\
& 0,08970357 \mathrm{D} Z_{2 t-8}
\end{array}
$$

Model SVAR digunakan untuk mendapatkan hasil peramalan 6 periode ke depan (27 Juni 2018 - 4 Juli 2018). Hasil peramalan ditunjukkan pada Tabel 2.

Tabel 2. Hasil Peramalan 6 Periode ke Depan

\begin{tabular}{ccc}
\hline Tanggal & $\begin{array}{c}\text { Volume } \\
\text { Perdagangan Saham }\end{array}$ & $\begin{array}{c}\text { Indeks } \\
\text { SahamConsumer } \\
\text { Goods }\end{array}$ \\
\hline 27 Juni 2018 & 718,23074 & 2414,84848 \\
28 Juni 2018 & 646,13693 & 2429,57135 \\
29 Juni 2018 & 647,58869 & 2438,80292 \\
02 Juli 2018 & 639,89969 & 2434,53167 \\
03 Juli 2018 & 744,55990 & 2442,16145 \\
04 Juli 2018 & 707,81069 & 2437,19059 \\
\hline
\end{tabular}

Evaluasi kinerja model dilakukan berdasarkan nilai MAPE pada data in sample variabel volume perdagangan saham bernilai $13,87434 \%$ dan indeks saham consumer goods bernilai $0,87045 \%$, sedangkan pada data out sample MAPE variabel volume perdagangan 
saham dan indeks saham consumer goods secara berturut-turut bernilai 14,22964\% dan $1,76054 \%$.

Analisis dampak shock yang disebabkan shock volume perdagangan saham (shock 1) dan shock indeks saham consumer goods (shock 2) padaindeks saham consumer goods ketika terjadi guncangan dijelaskan melaluivariance decomposition pada Tabel 3.

Tabel 3. Variance Decomposition of D(TIndeks Saham Consumer Goods)

\begin{tabular}{cccc}
\hline Periode & Standard Error & Shock 1 & Shock 2 \\
\hline 1 & 158276,8 & 0,477037 & 99,52296 \\
2 & 159717,3 & 1,753425 & 98,24658 \\
3 & 161533,1 & 3,938110 & 96,06189 \\
$\cdot$ & $\cdot$ & $\cdot$ & $\cdot$ \\
$\cdot$ & $\cdot$ & $\cdot$ & $\cdot$ \\
$\cdot$ & $\cdot$ & $\cdot$ & $\cdot$ \\
26 & 169739,6 & 9,920950 & 90,07905 \\
27 & 169740,8 & 9,921400 & 90,07860 \\
28 & 169745,2 & 9,925829 & 90,07417 \\
\hline
\end{tabular}

Respon D(TIndeks saham consumer goods) terhadap shock 1 adalah $\mathrm{D}$ (TIndeks saham consumer goods) akan cenderung meningkat sedangkan respon terhadap shock 2 akan menurun seiring bertambahnya periode hingga tercapainya kondisi equilibrium pada periode ke-26 dengan proporsi shock 1 sebesar 9,920950\% dan shock 2 sebesar $90,07905 \%$.

\section{KESIMPULAN}

Model VAR yang terbentuk dengan unsur pembentuknya stasioner setelah dilakukan transformasi dan pada derajat diferensi orde pertama sertalag optimum berdasarkan nilai AIC terkecil yaitu pada lag ke-8 adalah VAR(8) sebagai berikut:

$$
\begin{aligned}
& \mathrm{DT}_{1 t}=-0,00018908-0,71881701 \mathrm{D} Z_{1 t-1}-0,7098170 \mathrm{D} Z_{1 t-2}-0,54008186 \\
& \mathrm{D} Z_{1 t-3}-0,54440893 \mathrm{D} Z_{1 t-4}-0,43990211 \mathrm{D} Z_{1 t-5}-0,25514564 \mathrm{DZ}_{1 t-6}- \\
& 0,23737440 \quad \mathrm{D} Z_{1 t-7} \quad-0,19134005 \quad \mathrm{D}_{1 t-8}+9,20352 \mathrm{E}-10 \quad \mathrm{D} Z_{2 t-1}+ \\
& 3,92042 \mathrm{E}-10 \mathrm{D} Z_{2 t-2}+1,68632 \mathrm{E}-10 \mathrm{DZ}_{2 t-3}+2,67049 \mathrm{E}-09 \mathrm{DZ}_{2 t-4}+ \\
& \text { 2,52062E-09 DZ } Z_{2 t-5}-1,74351 \mathrm{E}-09 \mathrm{DZ}_{2 t-6}+1,40941 \mathrm{E}-09 \mathrm{DZ}_{2 t-7}+ \\
& \text { 3,90407E-09 } \mathrm{D} Z_{2 t-8} \\
& \mathrm{DTZ}_{2 t} \quad=\quad-\quad 3270,7348-4302568,56 \mathrm{D} Z_{1 t-1}-9419786,67 \mathrm{D} Z_{1 t-2^{-}} \\
& 11518317,8 \mathrm{D} Z_{1 t-3}-9782437,85 \mathrm{D} Z_{1 t-4}-8121980,61 \mathrm{D} Z_{1 t-5}-6279515,56 \\
& \mathrm{D} Z_{1 t-6}+3156572,05 \mathrm{D} Z_{1 t-7}+3983094,72 \mathrm{D} Z_{1 t-8}-0,07228907 \mathrm{D} Z_{2 t-1} \\
& +0,00187977 \mathrm{D} Z_{2 t-2}-0,02522519 \mathrm{D} Z_{2 t-3}+0,09374503 \mathrm{D} Z_{2 t-4}- \\
& 0,05573842 \mathrm{D} Z_{2 t-5}-0,00495236 \mathrm{D} Z_{2 t-6}+0,09932156 \mathrm{D} Z_{2 t-7}- \\
& 0,07909822 \mathrm{D} Z_{2 t-8}
\end{aligned}
$$

Model VAR(8) yang terbentuk memenuhi proses white noise residual dan berdistribusi normal k-variatserta berada dalam kondisi yang stabil sehingga model SVAR dengan restriksi $\mathbf{A}=\left[\begin{array}{cc}1 & 0 \\ -2716489 & 1\end{array}\right]$ yang terbentuk adalah sebagai berikut:

$$
\begin{aligned}
& \mathrm{DT} Z_{1 t}=-0,00018908-0,71881701 \mathrm{D} Z_{1 t-1}-0,7098170 \mathrm{D} Z_{1 t-2}-0,54008186 \\
& \mathrm{D} Z_{1 t-3}-0,54440893 \mathrm{DZ}_{1 t-4}-0,43990211 \mathrm{D} Z_{1 t-5}-0,25514564 \mathrm{DZ}_{1 t-6} \\
& 0,23737440 \quad \mathrm{D} Z_{1 t-7} \quad-0,19134005 \quad \mathrm{DZ}_{1 t-8}+9,20352 \mathrm{E}-10 \quad \mathrm{D} Z_{2 t-1}+ \\
& 3,92042 \mathrm{E}-10 \mathrm{D} Z_{2 t-2}+1,68632 \mathrm{E}-10 \mathrm{DZ}_{2 t-3}+2,67049 \mathrm{E}-09 \mathrm{DZ}_{2 t-4}+
\end{aligned}
$$




$$
\begin{array}{cccc} 
& 2,52062 \mathrm{E}-09 \mathrm{D}_{2 t-5}-1,74351 \mathrm{E}-09 \quad \mathrm{D} Z_{2 t-6}+ & 1,40941 \mathrm{E}-09 \mathrm{DZ}_{2 t-7}+ \\
& 3,90407 \mathrm{E}-09 \mathrm{D} Z_{2 t-8} \\
\mathrm{DT} Z_{2 t} & =\quad-\quad 3270,7348-4302568,56 \mathrm{D} Z_{1 t-1}-9419786,67 \mathrm{D} Z_{1 t-2^{-}} \\
& 11518317,8 \mathrm{D} Z_{1 t-3}-9782437,85 \mathrm{D} Z_{1 t-4}-8121980,61 \mathrm{D} Z_{1 t-5}-6279515,56 \\
& \mathrm{D} Z_{1 t-6}+3156572,05 \mathrm{D} Z_{1 t-7}+3983094,72 \mathrm{D} Z_{1 t-8}-0,07228907 \mathrm{D} Z_{2 t-1} \\
& +0,00187977 \mathrm{D} Z_{2 t-2}-0,02522519 \mathrm{D} Z_{2 t-3}+0,09374503 \mathrm{D} Z_{2 t-4}- \\
& 0,05573842 \mathrm{D} Z_{2 t-5}-0,00495236 \mathrm{D} Z_{2 t-6}+0,09932156 \mathrm{D} Z_{2 t-7} & - \\
& 0,07909822 \mathrm{D} Z_{2 t-8}
\end{array}
$$

Nilai MAPE pada data in sample variabel volume perdagangan saham bernilai $13,87434 \%$ dan indeks saham consumer goods bernilai $0,87045 \%$, sedangkan pada data out sample MAPE variabel volume perdagangan saham dan indeks saham consumer goods secara berturut-turut bernilai $14,22964 \%$ dan $1,76054 \%$.

Respon D(TIndeks saham consumer goods) terhadap shock 1 akan cenderung meningkat dan respon terhadapshock 2 akan cenderung menurun hingga mencapai kondisi equilibrium pada periode ke-26 dengan proporsi shock1 sebesar 9,920950\% dan proporsishock 2 sebesar 90,07905\%.

\section{DAFTAR PUSTAKA}

Ariefianto, M.D. 2012. Ekonometrika Esensi dan Aplikasi dengan Menggunakan EViews. Jakarta: Erlangga.

Aunuddin. 1989. Analisis Data. Bogor: Institut Pertanian Bogor.

Chang, P.C., Wang, Y.W., Liu, C.H. 2007. The Development of a Weighted Evolving Fuzzy Neural Network for PCB Sales Forecasting. Expert Systems with Applications. No. 32. Pages: 86-89.

Darmadji, T. dan Fakhtudidin, H.M. 2001. Pasar Modal di Indonesia Pendekatan Tanya Jawab, Edisi Pertama. Jakarta: PT Salemba Empat.

Enders, W. 2004. Applied Econometric Time Series. John Wiley \& Sony, Inc.

Gujarati, D.N. 2004. Basic Econometrics, Fourth Edition. New York: The McGraw-Hill.

Halim, A. dan Hidayat, N. 2000. Studi Empiris Tentang Pengaruh Volume Perdagangan dan Return Terhadap Bid-Ask Spread Saham Industri Rokok di BEJ dengan Model Korelasi Kesalahan. Jurnal Riset Akutansi Indonesia, Vol. 3, halaman 69-85.

Haryatmi, S. dan Guritno, S. 2008. Metode Statistika Multivariat, Edisi Kesatu. Universitas Terbuka

Hill, R.C., Griffiths, W.E., Lim, G.C. 2011. Principles of Econometrics, Fourth Edition. Wiley.

Lütkepohl, H. 2005. New Introduction to Multiple Time Series Analysis. Berlin: Springer.

Makridakis, S., Steven, C.W., dan Victor, E.M. 1992. Metode Dan Aplikasi Peramalan. Buku Pertama, Edisi Kedua. Jakarta: Erlangga.

Rosadi, D. 2012. Ekonometrika \& Analisis Runtun Waktu Terapan dengan EViews. Yogyakarta: Andi. 
Rusdin. 2008. Pasar Modal Teori, Masalah, dan Kebijakan dalam Praktik. Bandung: Alfabeta.

Soejoeti, Z. 1987. Analisis Runtun Waktu. Jakarta: Universitas Terbuka.

Sunariyah. 2010. Pengantar Pengetahuan Pasar Modal, Edisi Keenam. Yogyakarta: UPPAMP YPKN.

www.investing.com (diakses pada 23 Mei 2018) 